\title{
ENERGY VALORIZATION OF MISCANTHUS X GIGANTEUS BIOMASS: A CASE STUDY IN CROATIA
}

\section{ENERGETSKA VALORIZACIJA BIOMASE TRAVE MISCANTHUS X GIGANTEUS: STUDIJA SLUČAJA U HRVATSKOJ}

\author{
Nikola BILANDŽIJA, Vanja JURIŠIĆ, Neven VOĆA, Josip LETO, Ana MATIN, Mateja GRUBOR, Tajana KRIČKA \\ University of Zagreb Faculty of Agriculture, 10000 Zagreb, Svetošimunska cesta 25, Croatia \\ e-mail: nbilandzija@agr.hr
}

\begin{abstract}
The aim of this study is to determine the calorific values, chemical composition (proximate and ultimate analysis, micro and macro elements) and cell structure (composition of lignocellulose) of Miscanthus x giganteus biomass cultivated in Croatian. Research results represents the average values of biomass $(n=108)$ cultivated at two locations in Croatia (Bistra, Medvednica), during the three-year research period, three harvest periods (autumn, winter, spring) per year and two fertilizer treatments $\left(N_{0} i N_{50}\right)$. Determined average values of some important parameters are: low calorific value - $17.25 \mathrm{MJ} / \mathrm{kg}$, ash content - $1.49 \%$, carbon content $-48.75 \%$, nitrogen content $-0.47 \%$, sulfur content $-0.07 \%$, cellulose content $-49.22 \%$ and lignin content - $29.25 \%$. The obtained results have shown that Miscanthus $x$ giganteus has potential to be a significant source of good quality raw material in the production of solids biofuels.
\end{abstract}

Key words: energy crops, Miscanthus x giganteus, biomass properties

\section{REZIME}

Biomasa je prepoznata kao značajna izvor sirovina u proizvodnji „zelene energije“. Nakon nuklearne energije, ostalih tipova obnovljive energije te energije krutih fosilnih goriva, proizvedena energija iz biomase je trenutno četvrti najzastupljeniji energent $u$ Europskoj uniji. Jedan od načina proizvodnje biomase je i uzgoj poljoprivrednih energetskih kultura. Takva kultura je i višegodišnja sterilna trava Miscanthus x giganteus. Navedenu kulturu karakterizira mogućnost uzgoja na tlima lošije kvalitete, visok prinos suhe tvari po jedinici površine te izuzetna otpornost na bolesti i štetočine. Trenutna proizvodnja istraživane kulture u Europskoj uniji se provodina nešto više od 43.000 ha. Cilj ovoga rada je utvrditi ogrjevnu vrijednost (gornju i donju), kemijski sastav (gorive i ne gorive tvari, miko i makro elemente) te građu stanične stijenke (lignocelulozni sastav) biomase trave Miscanthus $x$ giganteus uzgojene na području Hrvatske. Istraživani parametri predstavljaju prosječne vrijednosti biomase (n=108) s dvije lokacije uzgoja (Bistra, Medvednica), tri godine istraživanja, tri roka žetve (jesenski, zimski, proljetni) po godini te dva gnojidbena tretmana ( $N_{0} i N_{50}$ ). Utvrđena prosječne vrijednosti nekih od važnijih parametara iznose za donju ogrijevnu vrijednost 17,25 MJ/kg, pepeo 1,49\%, ugljik 48,75\%, dušik 0,47\%, sumpor 0,07\%, celuloza 49,22\%, lignin 29,25\%. Dobiveni rezultati valoriziraju Miscanthus x giganteus kao potencijalno značajan izvor kvalitetne sirovine u proizvodnji krutih biogoriva.

Ključne riječi: energetske kulture, Miscanthus x giganteus, svojstva biomase.

\section{INTRODUCTION}

Miscanthus is a lignocellulosic perennial grass that has received significant interest because it displays a number of characteristics that make it a good source of biomass. These characteristics include high yield, cold tolerance, C4 photosynthesis, perenniality, non-invasiveness, low requirement for inputs such as fertilisers and herbicides, ease of harvesting and handling (Jørgensen, 2011; Robson et al., 2012).Miscanthus $x$ giganteus can be harvested from November (after early frosts) until the beginning of the following vegetation cycle (March, April). Generally, early harvesting will maximize the yield per hectare while late harvest will lower it (Lewandowski et al., 2003; Zub et al., 2011). Due to leaf and stem apex fall, the yield tends to lower by 33-38 \% on average from the October harvest until February harvest time (Dželetović et al., 2014).

The primary energy utilization of the mentioned crop is in direct combustion, but certainly it should be emphasized that this crop has a very significant potential in the production of second generation biofuels (Bilandžija et al., 2016). Direct combustion is now the most widespread way of extracting energy from biomass and it can be applied to several fuel materials: energy crops, agriculture residues, forest residues, industrial and other wastes (Elbehri, 2013). In terms of combustion, the most important biomass properties include: proximate analysis, ultimate analysis, heating value (Imam and Capareda, 2012), lignocellulosic composition and the contents of micro-macro elements. Currently, Miscanthus x giganteus is cultivated on more than 43,000 ha in the European Union (ABIOM, 2016). In Croatia, commercial plantations of the investigated culture do not exists, but in 2011 the first trial fields were set up. Based on performance of these fields, the authors Leto et al., (2016) conclude that dry matter yields of Miscanthus $x$ giganteus grown in different agro-ecological conditions in Croatia without irrigation and in drought years can be competitive to the yields realized in the most favourable south European habitats with application of irrigation.

Among other agricultural and forest biomass types, CEN/TS 14961:2005 standard for solid fuels determines the typical values for Miscanthus $x$ giganteusas well. The mention standard is based on researches conducted in Sweden, Finland, Netherlands and Germany. It is important to note that characteristics of biomass are influenced by its origin, and give a wide variety of 
fuel properties (Garcia et al., 2012). In all types of biomass, Miscanthus $x$ giganteus included, CEN/TS 14961:2005 only applies to some parameters of combustion properties.

The aim of this study is to determine the calorific values, chemical composition (proximate and ultimate analysis, micro and macro elements) and cell structure (composition of lignocellulose) of Miscanthus $x$ giganteus biomass cultivated in Croatia. The results obtained from this research refer to the average values $(n=108)$ of biomass cultivated at two locations in Croatia (Bistra, Medvednica), during a three-year period, three harvest periods per year (autumn, winter, spring) and two fertilizer treatments $\left(\mathrm{N}_{0}\right.$ and $\left.\mathrm{N}_{50}\right)$. The obtained results will be compared with the average literature values and the CEN/TS 14961:2005 standard for solid fuels.

\section{MATERIAL AND METHOD}

\section{Materials (field trials)}

The trial field schemes on both locations are identical. The basic plot has a surface of $60 \mathrm{~m}^{2}(3 \times 20 \mathrm{~m})$, with a 2 metre distance between the plots. Both trial fields are set as 2-factorial trial in split-plot design in three replications. Fertilization is the main factor of the investigation $\left(\mathrm{N}_{0} \mathrm{P}_{0} \mathrm{~K}_{0}\right.$ - without introducing nutrients, and $\mathrm{N}_{60} \mathrm{P}_{60} \mathrm{~K}_{90}-60 \mathrm{~kg} \mathrm{~N}, 60 \mathrm{~kg} \mathrm{P}_{2} \mathrm{O}_{5}$ and $90 \mathrm{~K}_{2} \mathrm{O}$ ), while harvest times are sub-factor (autumn, winter and spring harvest times), which makes six treatments overall. The result of the research is the average values $(n=108)$ of biomass.

Methods

Before the analysis, all samples were dried in order to eliminate extrinsic moisture and to enable comparison of the samples in identical operative conditions. After drying, samples were ground in a laboratory grinder (IKA Analysentechnik $\mathrm{GmbH}$, Germany). Each sample was analysed at least three times in order to provide reproducibility of the analyses.

Heating value was determined by ISO method (EN 14918:2010) using an IKA C200 oxygen bomb calorimeter (IKA Analysentechnik GmbH, Heitersheim, Germany). A 0.5-gram sample was weighed in a quartz crucible and put in a calorimeter for combustion. Higher heating value was obtained after combustion by means of IKA C200 software. Heating value is reported in $\mathrm{MJ} / \mathrm{kg}$ on dry basis.

The samples were characterized by proximate analysis according to standard methods: moisture content (CEN/TS 14774-2:2009) was determined in laboratory oven (INKO ST40, Croatia); while ash (CEN/TS 14775:2009), fixed carbon (by difference), and volatile matter (CEN/TS 15148:2009) were determined by use of muffle furnace (Nabertherm GmbH, Nabertherm Controller B170, Germany).

Total carbon, hydrogen, nitrogen and sulphur were determined simultaneously by method of dry combustion in a Vario Macro CHNS analyser (ElementarAnalysensysteme GmbH, Germany), according to the protocols for determining carbon, hydrogen and nitrogen (EN 15104:2011) and sulphur (EN 15289:2011). Oxygen content was calculated by difference.

The contents of all analysed elements: sodium, calcium, potassium, magnesium, iron, manganese, zinc, copper, chromium, lead, nickel, and cobalt, were determined by atomic absorption spectrometry (CEN/TS 15290:2006, CEN/TS 15297:2006; Determination of minor elements, 2006).
Cellulose, hemicellulose and lignin content was determined by the standard ISO 5351-1:2002 method.

\section{RESULTS AND DISCUSSION}

Calorific value, proximate and ultimate analysis, micromicro elements and lignocellulosic composition are considered to be among the essential parameters in evaluation of biomass in the direct combustion process. The main properties of raw materials as energy sources are included into investigation and the mentioned values are presented in Tables 1,2,3,4 and 5. Also, the desirable values (higher $(+)$ and lower $(-)$ ) of investigated parameters, are presented in the tables. Table 1 shows average calorific value of Miscanthus $x$ giganteus biomass cultivated at the territory of Croatia $(n=108)$ and the literature data of the analysis of the biomass grown from different countries.

Table 1. Average calorific value of Miscanthus x giganteus biomass

\begin{tabular}{||l|c|c||}
\hline \hline Parameter & $\begin{array}{c}\text { Higher } \\
\text { calorific value }\end{array}$ & $\begin{array}{c}\text { Lower } \\
\text { calorific value }\end{array}$ \\
\hline Unit & $\mathrm{MJ} / \mathrm{kg}, \mathrm{dm}$ & $\mathrm{MJ} / \mathrm{kg}, \mathrm{dm}$ \\
\hline Desirable value Country of cultivation \\
\hline \multicolumn{2}{|c|}{+} \\
\hline Croatia & $18.19 \pm 0.27$ & $17.25 \pm 0.32$ \\
\hline Spain (Garcia et al., 2012) & 19.80 & - \\
\hline $\begin{array}{l}\text { United Kingdom } \\
\text { (Mos et al., 2013) }\end{array}$ & 18.13 & 16.55 \\
\hline France (Jeguirim et al., 2009) & 17.80 & - \\
\hline Serbia (Cvetković et al., 2016) & 16.55 & 15.31 \\
\hline
\end{tabular}

The term calorific value refers to energy content of raw materials and it characterizes a biomass sample as a possible fuel resource. The calorific value can be expressed by higher and lower heating value (McKendry, 2002; Garcia et al., 2012).CEN/TS 14961:2005 norm for solid fuels defines typical values of $\mathrm{HHV}$ and $\mathrm{LHV}$ of $19.8 \mathrm{MJ} / \mathrm{kg}$ and $18.4 \mathrm{MJ} / \mathrm{kg}$, successively. Comparing the presented values of Miscanthus $x$ giganteus biomass cultivated in Croatia to the norm it can be observed that the values are lower. However, the analyzed samples show that average calorific value is better than respective values found in the United Kingdom, France and Serbia, while it is not the case when the samples are compared to biomass grown in Spain. Table 2 shows the average proximate analysis of Miscanthus $x$ giganteusbiomass cultivated in Croatia

Table 2. Average proximate analysis of Miscanthus x giganteus biomass

\begin{tabular}{|c|c|c|c|c|}
\hline Parameter & Moisture & $\begin{array}{c}\begin{array}{c}\text { Fixed } \\
\text { carbon }\end{array} \\
\end{array}$ & Ash & $\begin{array}{c}\text { Volatile } \\
\text { matter }\end{array}$ \\
\hline Unit & $\%, a r^{*}$ & $\%, \mathrm{dm}$ & $\%, \mathrm{dm}$ & $\%, \mathrm{dm}$ \\
\hline Influence & - & + & - & - \\
\hline \multicolumn{5}{|c|}{ Country of cultivation } \\
\hline Croatia & $\begin{array}{c}35.30 \pm \\
14.85 \\
\end{array}$ & $\begin{array}{c}9.77 \pm \\
1.03 \\
\end{array}$ & $\begin{array}{c}1.50 \pm \\
0.40 \\
\end{array}$ & $\begin{array}{c}86.52 \pm \\
3,43 \\
\end{array}$ \\
\hline $\begin{array}{l}\text { Germany } \\
\text { (Lewandowski and Heinz, 2003) }\end{array}$ & 31.50 & - & - & - \\
\hline Poland (Borkowska and Molas, 2013) & 42.70 & - & - & - \\
\hline Spain (Garcia et al., 2012) & - & 11.40 & 9.60 & 79.00 \\
\hline United Kingdom (Mos et al., 2013) & - & 18.97 & 5.30 & 76.60 \\
\hline France (Jeguirim et al., 2009) & - & 9.50 & 2.70 & 78.80 \\
\hline Serbia (Cvetković et al., 2016) & - & - & 1.75 & - \\
\hline Italy (Mantineo, 2009) & - & - & 3.80 & - \\
\hline Ireland (Meehan et al., 2013) & - & - & 1.51 & - \\
\hline
\end{tabular}

$*$ as received 
$(\mathrm{n}=108)$ and the literature data of biomass analysis from different countries. Heating value decreases with higher moisture content, so that its excessive levels can reduce combustion temperatures and affect quality (Garcia et al., 2012). Higher portion of fixed carbon affects the quality of biomass because of its increased heating value (McKendry, 2002; Obernberger and Thek, 2004). Fixed carbon produces char and burns as a solid material in the combustion system (Khodier et al., 2012). CEN/TS 14961 norm does not state the typical values for moisture content and fixed carbon. Based of the data presented in Table 2 it can be concluded that the average moisture content is lower compared to that obtained in Germany, but better compared to the result obtained in Poland. It is important to mention that the most significant influence on moisture content comes from climate meteorological parameters during the period of biomass harvesting. In case of average fixed carbon content, the analysed samples in Croatia show poorer values in relation to those in Spain and the United Kingdom, but better ones when compared to the analysed values from France. Ash consists of the incombustible inorganic remnants of combustion. Some of these inorganic materials come from the biomass fuel itself, and some, e.g., soil particles become incorporated during processing (Khan et al., 2009). CEN/TS 14961:2005 solid fuels states that the differences in ash content in Miscanthus $x$ giganteus biomass could be expected to be between $1 \%$ and $6 \%$. The average analysed value of ash in this paper is in the expected lower range. Similar average values were observed in the investigations conducted in Serbia and Ireland, and the largest differences were observed in Miscanthus x giganteus grown in Spain.

The burning of volatiles is generally quite rapid and occurs as quickly as volatiles are released (Jenkins, 1998). The concept of volatile matter refers to the components released when fuel is heated at a high temperature, without counting moisture, being part combustible gases (CxHy gases, $\mathrm{CO}$ or $\mathrm{H}_{2}$ ) and part incombustible $\left(\mathrm{CO}_{2}, \mathrm{SO}_{2}\right.$ or $\left.\mathrm{NOx}\right)$ (Garcia et al., 2012). As in the case of moisture and fixed carbon, CEN/TS 14961:2005 solid fuels norm does not set out typical values for volatile matter. Comparison with the investigations conducted in Spain, the United Kingdom and in France shows that Miscanthus $x$ giganteus grown in Croatia has a higher volatile matter content.

Table 3 presents the average ultimate analysis of Miscanthus $x$ giganteus biomass cultivated in Croatia $(\mathrm{n}=108)$ and the literature data of the analysis of biomass grown in different countries

The main components of solid biofuels are $\mathrm{C}, \mathrm{H}$ and $\mathrm{O}$. Both $\mathrm{C}$ and $\mathrm{H}$ are oxidised during combustion via an exothermic reaction, resulting in the formation of $\mathrm{CO}_{2}$ and $\mathrm{H}_{2} \mathrm{O}$ (Obernberger et al., 2006). A higher carbon and hydrogen content leads to a higher heating value (Clarke and Preto, 2011). CEN/TS 14961:2005 solid fuels norm shows typical values for $\mathrm{C}, \mathrm{H}, \mathrm{O}$ which are $49 \%, 6.4 \%$ and $44 \%$, successively. Comparison with the average values determined in Croatia shows a minor difference in $\mathrm{C}$ content and somewhat larger difference in $\mathrm{H}$ and $\mathrm{O}$ contents. Unlike biomass grown in other countries, the biomass grown in Croatia has higher $\mathrm{C}$ and $\mathrm{O}$ content and the lowest $\mathrm{H}$ content. Since nitrogen and sulphur influence the emissions of harmful gases $\left(\mathrm{NOx}\right.$ and $\left.\mathrm{SO}_{2}\right)$ during biomass combustion, concentrations of these gases should be as low as possible. Sulphur is the element with the lowest presence in biomass, but from environmental point of view it is, together with nitrogen, a critical element (Garcia et al., 2012; Sáez Angulo and Martínez García, 2001). According to CEN/TS 14961:2005 solid fuels norm, typical value for $\mathrm{N}$ is $0.7 \%$, and for S $0.2 \%$. As a result, it can be observed that both analysed values of these parameters are below the typical values set out by the solid fuels norm. Miscanthus $x$ giganteus grown in Croatia has higher $\mathrm{N}$ content than the grass cultivated in Spain, Serbia and Ireland, while higher S content was found in France, Ireland and Spain.

Table 4 shows the average analysis of lignocellulosic composition of Miscanthus $x$ giganteus biomass cultivated in Croatia $(n=108)$ and literature data of the analysis of biomass from the United Kingdom.
Table 4. Average analysis of lignocellulosic composition of Miscanthus $x$

giganteus biomass
\begin{tabular}{||l|c|c|c||}
\hline Parameter & Cellulose & Hemicellulose & Lignin \\
\hline Desirable value & $\%, \mathrm{dm}$ & $\%, \mathrm{dm}$ & $\%, \mathrm{dm}$ \\
\hline \multicolumn{4}{|c|}{ Country of cultivation } \\
\hline Croatia & $49.22 \pm 0.14$ & - & + \\
\hline $\begin{array}{l}\text { United Kingdom } \\
\text { (Hodgson et al, 2011; Brosse et al, 2012) }\end{array}$ & 50.33 & 25.30 & 13.30 \\
\hline
\end{tabular}

Lignocellulose is the material which makes the basis of the plant's cell wall consisting of three main components: lignin, cellulose and hemicellulose. Lignin constitutes the key component of the cell wall, and biomass with higher lignin content is more suitable for electricity / heat energy production by direct combustion (McKendry, 2002; Predojević, 2010; Hodgson et al., 2010). Cellulose and hemicellulose have higher oxygen content in relation to lignin, so cellulose has lower heating value than lignin (Lewandowski et al., 2003). CEN/TS 14961 norm does not state the typical values for lignocellulosic composition, and comparing with literature data from the United Kingdom hemicellulose content is lower while lignin content is quiete higher. Haffner et al., 2013 in Illinois (USA) determined lignin content range from 17.51 to $23.19 \%$. Based on the presented data, it can be concluded that the share of lignin content is under the strong influence of agro-ecological conditions.

Table 5 shows the average analysis of minor and major elements of Miscanthus $x$ giganteus biomass grown in Croatia 
( $\mathrm{n}=108)$ and typical values from CEN/TS 14961:2005 solid fuels. Given the number of conducted analyses, minor and major elements were not compared to those from other locations where the Miscanthus $x$ giganteus is cultivated. The ash-forming elements such as $\mathrm{Al}, \mathrm{Si}, \mathrm{Ca}, \mathrm{Fe}, \mathrm{K}, \mathrm{Mg}, \mathrm{Na}$ and $\mathrm{P}$ in biomass are especially important for any thermochemical conversion process. The relatively high contents of alkali may lead to a serious technical problem when used as feedstock for power production. It is generally believed that alkali metals are the main cause of slagging, fouling and sintering (Cuiping et al., 2004). If the analysed values of Miscanthus $x$ giganteus grown in Croatia are compared with typical value of CEN/TS 14961:2005 solid fuels, it can be observed that iron, magnesium, calcium, lead and nickel values are fully compatible with the norm. Minor discrepancies are observed in copper and potassium, and larger ones in zinc and sodium.

Table 5. Average analysis of minor and major elements of Miscanthus x giganteus biomass ( $\mathrm{mg} / \mathrm{kg}, \mathrm{d} . \mathrm{m}$.)

\begin{tabular}{|c|c|c|c|c|}
\hline Parameter & Unit & $\begin{array}{c}\text { Desirable } \\
\text { value }\end{array}$ & Croatia & $\begin{array}{c}\text { CEN/TS } \\
14961: 2005\end{array}$ \\
\hline Copper & $\mathrm{mg} / \mathrm{kg}, \mathrm{dm}$ & - & $5.30 \pm 0.97$ & $1-5$ \\
\hline Zinc & $\mathrm{mg} / \mathrm{kg}, \mathrm{dm}$ & - & $53.01 \pm 18.70$ & $10-20$ \\
\hline Iron & $\mathrm{mg} / \mathrm{kg}, \mathrm{dm}$ & - & $221.85 \pm 107.57$ & $40-400$ \\
\hline Sodium & $\mathrm{mg} / \mathrm{kg}, \mathrm{dm}$ & - & $80.67 \pm 27.69$ & $200-500$ \\
\hline Potassium & $\mathrm{mg} / \mathrm{kg}, \mathrm{dm}$ & - & $920.61 \pm 289.35$ & $1000-11000$ \\
\hline Magnesium & $\mathrm{mg} / \mathrm{kg}, \mathrm{dm}$ & $-/+$ & $439.13 \pm 59.72$ & $300-900$ \\
\hline Calcium & $\mathrm{mg} / \mathrm{kg}, \mathrm{dm}$ & $-/+$ & $1854 \pm 473.44$ & $900-3000$ \\
\hline Manganese & $\mathrm{mg} / \mathrm{kg}, \mathrm{dm}$ & - & $102.65 \pm 81.25$ & - \\
\hline Chromium & $\mathrm{mg} / \mathrm{kg}, \mathrm{dm}$ & - & $<0.25$ & $0.4-6.0$ \\
\hline Lead & $\mathrm{mg} / \mathrm{kg}, \mathrm{dm}$ & - & $<0.25$ & $<0.5-5.0$ \\
\hline Nickel & $\mathrm{mg} / \mathrm{kg}, \mathrm{dm}$ & - & $<0.25$ & $0.5-5.0$ \\
\hline Cobalt & $\mathrm{mg} / \mathrm{kg}, \mathrm{dm}$ & - & $<0.25$ & - \\
\hline
\end{tabular}

\section{CONCLUSION}

Given the fact that biomass of Miscanthus $x$ giganteus grass is currently mostly used as a raw material for combustion in the process of heat and/or electricity production, it is important to determine combustion properties of this raw material. The laboratory analyses of all investigated parameters are compatible with or somewhat diverge from the available literature data and/or CEN/TS 14961 for solid fuel. Certain divergences from mention sources prove that the influence of agro-ecological conditions on the properties of cultivated biomass is significant and also indicate the importance of customized approach to each individual location where the biomass is cultivated.

ACKNOWLEDGMENT: This research was funded by the Croatian Science Foundation, the project no. 3328, "Converting waste agricultural biomass and dedicated crops into energy and added value products - bio-oil and biochar production".

\section{REFERENCES}

AEBIOM (2016). European biomass association, Statistical report - European bioenergy outlook. Brussels, Belgium.

Bilandžija, N., Jurišić, V., Voća, N., Leto, J., Matin, A., Antonović, A., Krička, T. (2016). Lignocelulozni sastav trave Miscanthus $x$ giganteus u odnosu na različite tehnološke i agroekološke uvjete. Zbornik radova, 51. hrvatskog i 11. međunarodnog simpozija agronoma, Sveučilište u Zagrebu Agronomski fakultet, Opatija, Hrvatska, 450-454.
Borkowska, H, Molas, R. (2013). Yield comparison of four lignocellulosic perennial energy crop species. Biomass and Bioenergy, 51, 145-153.

Brosse, N., Dufour, A., Meng, X., Sun, Q., Ragauskas, A. (2012). Miscanthus: a fast- growing crop for biofuels and chemicals production. Biofuels, Bioproducts and Biorefining, 6, 580-598.

CEN/TC 14961 (2005). Biomass standards - Fuel specifications and classes.

Clarke, S., Preto F. (2011). Biomass Burn Characteristics. Factsheet,ISSN 1989-712X, 11-033.

Cuiping, L., Chuangzhi, W., Yanyongjie, M., Haitao, H. (2004). Chemical elemental characteristics of biomass fuels in China. Biomass and Bioenergy, 27, 119-130.

Cvetković, O., Pivić, R., Dinić, Z., Maksimović, J., Trifunović, S., Dželetović, Ž. (2016). Hemijska ispitivanja miskantusa gajenog u Srbiji - Potencijalni obnovljiv izvor energije. Zaštita Materijala, 57 (3), 412-417.

Dželetović, Ž., Maksimović, J., Živanović I. (2014). Yield of Miscanthus $\times$ giganteus during crop establishment at two locations in Serbia. Journal on Processing and Energy in Agriculture, 18 (2), 62-64.

Elbehri, A., Segerstedt, A., Liu, P. (2013). Biofuels and the sustainability challenge: aglobal assessment of sustainability issues, trends and policies for biofuels and related feedstocks. Food and Agriculture Organization of the United Nations (FAO), Rome, Italy.

Garcia, R., Pizarro, C., Lavín, A.G., Bueno, J.L. (2012). Characterization of Spanish biomass wastes for energy use. Bioresource Technology, 103, 249-258.

Haffner, F.B., Mitchell, V.D., Arundale, R.A., Bauer, S. (2013). Compositional analysis of Miscanthus giganteus by near infrared spectroscopy. Cellulose, 20, 1629-1637

Hodgson, E.M., Fahmi, R., Yates, N., Barraclough, T., Shield, I., Allison, G., Bridgwater, A.V., Donnison, I.S. (2010). Miscanthus as a feedstock for fast-pyrolysis: Does agronomic treatment affect quality? Bioresource Technology, 101, 61856191.

Hodgson, E.M., Nowakowski, D.J., Shield, I., Riche, A., Bridgwater, A.V., Clifton-Brown, J.C., Donnison, I.S. (2011). Variation in Miscanthus chemical composition and implications for conversion by pyrolysis and thermo-chemical bio-refining for fuels and chemicals. Bioresource Technology, 102, 3411-3418.

Imam, T., Capareda, S. (2012). Characterization of bio-oil, syngas and bio-char from switchgrass pyrolysis at various temperatures. Journal of Analytical and Applied Pyrolysis, 93,170-177.

Jeguirim, C., Dorge, S., Trouvé, G. (2009). Thermogravimetric analysis and emission characteristics of two energy crops in air atmosphere: Arundo donax and Miscanthus giganthus. Bioresource Technology, 101, 778-793.

Jenkins, B.M., Baxter, L.L., Miles, Jr. T.R., Miles, T.R. (1998). Combustion properties of biomass. Fuel Processing Technology, 54, 17-46.

Jørgensen, U. (2011). Benefits versus risks of growing biofuel crops: the case of Miscanthus, Current Opinion in Environmental Sustainability, 3 (1-2), 24-30.

Khan, A.A., Jonga, W.D., Jansens, P.J., Spliethoff, H. (2009). Biomass combustion in fluidized bed boilers: potential problems and remedies. Fuel Processing Technology, 90, 2150 . 
Khodier, A.H.M., Hussain, T., Simms, N.J., Oakey, J.E., Kigallon, P.J. (2012). Deposit formation and emissions from co-firing miscanthus with Daw Mill coal. Pilot plant experiments. Fuel, 101, 53-61.

Leto, J., Bilandžija, N., Bošnjak, K., Vranić, M., Stuburić, I. (2016). Uzgoj Miscanthus x giganteus Greef et Deu. u različitim agroekološkim uvjetima Hrvatske - četverogodišnje iskustvo. Zbornik radova, 51. hrvatskog i 11. međunarodnog simpozija agronoma, Sveučilište u Zagrebu Agronomski fakultet, Opatija, Hrvatska, 233-237.

Lewandowski, I., Clifton-Brown, J.C., Andersson, B., Basch, G., Christian, D.G., Jorgensen, U., Jones, M.B, Riche, A.B., Schwarz, K.U., Tayebi, K., Texerija, F. (2003). Enviroment and harvest time affect the combustion qualities of Miskantus genotypes. Agronomy Journal, 95, 1274-1280.

Lewandowski, I., Heinz A. (2003). Delayed harvest of miscanthus - influences on biomass quantity and quality and environmental impacts of energy production. European Journal of Agronomy, 19, 45-63.

Mantineo, M., Agosta, G.M.D., Copani, V., Patanè, C., Cosentino.S.L. (2009). Biomass yield and energy balance of three perennial crops for energy use in the semi-arid Mediterranean environment. Field Crops Research, 114, 204213.

McKendry, P. (2002). Energy production from biomass (part 1). Overview of biomass. Bioresource Technology, 83, 37-46.

Meehan, P.G., Finnan, J.M., Mc Donnell, K.P. (2013). The effect of harvest date and harvest method on the combustion characteristics of Miscanthus $\times$ giganteus. GCB Bioenergy, 5 , 487-496.

Mos, M., Banks, S.W., Nowakowski, D.J., Robson, P.R.H., Bridgwater, A.V., Donnison, I.S (2013). Impact of Miscanthus $x$ giganteus senescence times on fast pyrolysis bio-oil quality. Bioresource Technology, 129, 335-342.

Obernberger, I., Brunner, T., Bärnthaler, G. (2006). Chemical properties of solid biofuels-significance and impact. Biomass and Bioenergy, 30, 973-82.

Obernberger, I., Thek, G. (2004). Physical characterisation and chemical composition of densified biomass fuels with regard to their combustion behaviour. Biomass and Bioenergy, 27, 653-669.

Predojević, Z. (2010). Postupci pripreme lignocelulozne sirovine za dobivanje bietanola. Hemijska industrija, 64, 283-310.

Robson, P., Mos M., Clifton-Brown J., Donnison I. (2012). Phenotypic Variation in Senescence in Miscanthus: Towards Optimising Biomass Quality and Quantity. BioEnergy Research, 5, 95-105.

Sáez Angulo, F., Martínez García, J.M. (2001). Emisiones en la combustión de biomasa y el medio ambiente. Energia, 161, 75-83.

Zub, H.W., Arnoult, S., Brancourt-Hulmel, M. (2011). Key traits for biomass production identified in different Miscanthus species at two harvest dates. Biomass and Bioenergy, 35, 637651.

Received: 14. 03. 2017.

Accepted: 03. 04. 2017. 